\title{
Implementation of Muhammadiyah Da'wah Through Local Cultural Wisdom in The Construction of Ummatan Wasathon in Lampung
}

\author{
Junaidi Songidan $^{1}$, Nasor ${ }^{2}$, Marzuki Noor ${ }^{3}$, Fitri Yanti ${ }^{4}$ \\ ${ }^{1,3}$ Universitas Muhammadiyah Metro, ${ }^{2,4}$ UIN Raden Intan Lampung
}

\begin{abstract}
This article focuses on research on the implementation of Muhammadiyah da'wah through local cultural wisdom in the 'ummatan wasathon' construction in Lampung. This study uses a qualitative method with a phenomenological and sociological approach to informants taken through purposive sampling with predetermined considerations. Data were collected through interviews, observation and documentation studies. The purpose of this study is to analyze the implementation of Muhammadiyah's da'wah and find out a model of Muhammadiyah's da'wah through local cultural wisdom in the construction of wasathon ummatan. The research findings show that Muhammadiyah's da'wah in implementing the Islamic da'wah movement requires movement reconciliation, through majlis and business charities, so that the da'wah movement can achieve its goals. At the same time, the da'wah is carried out with flexibility and wisdom through local cultural wisdom and becomes a model for the development of Islamic society, namely ummatan wasathon.
\end{abstract}

Keywords: Muhammadiyah, Lampung, Ummatan Wasathon

\section{Implementasi Dakwah Muhammadiyah Melalui Kearifan Budaya Lokal dalam Konstruksi Ummatan Wasathon (Studi Dakwah Muhammadiyah di Lampung)}

\begin{abstract}
Abstrak
Artikel ini fakus pada penelitian tentang Implementasi dakwah Muhammadiyah melalui kearifan budaya lokal dalam kontruksi ummatan wasathon di Lampung. Penelitian ini menggunakan metode kualitatif dengan pendekatan fenomenologis dan sosiologis terhadap Informan yang diambil melalui purposif sampling dengan pertimbangan yang telah ditetapkan. Data dikumpulkan melalui wawancara, observasi dan studi dokumentasi. Tujuan penelitian ini menganalisis implementasi dakwah Muhammadiyah dan menemukan model dakwah Muhammadiyah melalui kearifan budaya lokal dalam kontruksi ummatan wasathon. Temuan penelitian menunjukkan bahwa dakwah Muhammadiyah dalam mengimplementasikan gerakan dakwah Islam membutuhkan rekonsialisasi gerakan, melalui majlis-majlis dan amal usaha, sehingga dalam gerakan dakwahnya dapat mencapai sasaran. Di sisi lain dakwahnya dilakukan dengan fleksibilitas dan kebijaksanaan melalui kearifan budaya lokal, dan menjadi model pengembangan masyarakat Islam yaitu ummatan wasathon.
\end{abstract}

Kata Kunci: Muhammadiyah, lampung, ummatan wasathon

Author correspondence

Email: junaidisongi@gmail.com

Available online at http://journal.iaingorontalo.ac.id/index.php/au/index 


\section{A. Introduction}

Organizations in Muhammadiyah have a tremendous and significant influence on people's lives in Indonesia, which have a management structure, AD/ART, and others. ${ }^{1}$ Muhammadiyah, as a community organization that is more than a century old, has been active in spreading goodness. In the development from time to time, "the da'wah movement carried out by Muhammadiyah is a creative effort in fulfilling the call of revelation and overcoming various problems of human life sociologically which cannot be separated from changes in the society in which it develops." Even before the establishment of Muhammadiyah, there were many deviations from the teachings of Islam, as is known among some Muslims by "practices of shirk, superstition, bid'ah, and khurofat, which are cultural practices. syncretic Islamic society, and this is part of traditional Islamic practices. $^{2}$

The efforts made by KH. Ahmad Dahlan in straightening the teachings of Islam. Cultural challenges (culture) do not mean obstacles but are challenges that must be solved. ${ }^{3}$ For this reason, Muhammadiyah is here to provide enlightenment as a solution in various fields of community life. According to Din Syamsudin, "that Muhammadiyah needs flexibility in da'wah. Muhammadiyah is a da'wah movement because da'wah is an obligation for everyone, da'wah will be carried out in various ways, and the community can accept that. ${ }^{4}$

Muhammadiyah will always move to the rhythm of society in responding to the challenges of da'wah. The more you follow the flow of the path of da'wah, the more biased you appear, even if you almost drift along with the flow of culture. However, it should not be carried away by following the practices of some traditional societies, let alone drowning. Thus the implementation of the Muhammadiyah Da'wah movement needs a shift or needs to expand the path of da'wah from urban communities to rural communities. This movement requires a

\footnotetext{
${ }^{1}$ Anggaran Dasar Dan Anggaran Rumah Tangga Muhammadiyah, 5th ed. (Yogyakarta: Surya Sarana Grafika, 2010), http://www.suara-muhammadiyah.or.id.

${ }_{2}^{2}$ Muji Mulia, Islam Dan Transformasi Sosial Dalam Perspektif Kuntowijoyo , No. 2 (2018): 121-23.

${ }^{3}$ Nur Ahmad, Tantangan Dakwah Di Era Teknologi Dan InformasI No.1 (2013): 79.

4 Din Syamsudin, Muhammadiyah Untuk Semua, Penerbit Suara Muhammadiyah, Yogyakarta, 2014; p. 5
} 
strategy of da'wah's path because what is being faced is a syncretic Islamic community and a traditional Islamic society. ${ }^{5}$

Muhammadiyah's da'wah movement is supported by all components in the Muhammadiyah association, starting from the highest leadership to the lowest leadership, even all those related to Muhammadiyah. This leadership is the effort of Muhammadiyah's da'wah movement, which now prioritizes the flexibility of the movement in da'wah. Of course, this does not mean to obscure the ideology of Muhammadiyah's understanding or to bias Muhammadiyah's da'wah, but an effort to make Muhammadiyah's da'wah path so that it can be in the midst of people's lives and be accepted as part of the behavior of people's lives, even to get sympathizers from the periphery. However, not only that, but one's hope is to become part of Muhammadiyah's religious ideology, namely to become a truly Islamic society, starting from its correct aqidah, worship following the guidance of the Prophet Muhammad, and noble character and good relationship. ${ }^{6}$

Muhammadiyah, in implementing the way of da'wah, will be flexible, especially now with various approaches that will be taken. Through local cultural wisdom, Muhammadiyah strives to achieve da'wah goals according to local wisdom. It is a reality that Muhammadiyah residents living in rural areas will be faced with diverse local cultures, it could be that their kemuhammadiyah will be biased, it will be difficult to distinguish Muhammadiyah or traditional Islam, when seen as one congregation, for example in a congregation of yasin congregations, baby champions, group of citizens, marhabanan, kendurian, salvation. On the other hand, Muhammadiyah wants to be part of a unified community life, which is harmonious, peaceful in the midst, does not discriminate, whether it is Muhammadiyah or not. More importantly, its existence is recognized. ${ }^{7}$

The results of a survey conducted by researchers on 2 December 2018-28 September 2020 in some areas of Muhammadiyah Braja Selebah, East Lampung,

\footnotetext{
5Umar Umar, "Strategi Dakwah Kultural Muhammadiyah pada Ritual Adat Mappogau Hanua Masyarakat Karampuang Sinjai," Afkaruna: Indonesian Interdisciplinary Journal of Islamic Studies 13, no. 2 (2017): 206-7, doi:10.18196/AIIJIS.2017.0073.204-239.

6Syamsul Hidayat, Metode Pemahaman Agama Dalam Muhammadiyah Kajian Atas al-Masail alKhams dan $M K C H, "$, p.135-41.

7“Tinjauan Buku: Spirit Gerakan Muhammadiyah terhadap Kebudayaan, 2020, https://pmb.lipi.go.id/tinjauan-buku-spirit-gerakan-muhammadiyah-terhadap-kebudayaan/.
} 
Sendang Agung of Central Lampung, Candipuro of South Lampung, as members of Muhammadiyah within rural communities, who are faced with the habit of doing local cultural activities such as "yasinan" which has been going on for years until the child descends. One time this Muhammadiyah resident was invited to attend the event. However, one was confused, with various ways to avoid the invitation, on the one hand as a neighbor, on the other hand as a member of Muhammadiyah who is not used to doing the event, if one comes to the invitation, one will drown in the event, even though one was a Muhammadiyah person, but on the other hand was not sure to become a member of Muhammadiyah, he finally found a middle way solution. This fact occurs not only in one area, but it is possible that in other areas it occurs because of different regions, the program is the same "Yasinan congregation, baby champion, community group, marhabanan, kendurian, salvation, so the efforts made are through an approach local cultural wisdom.

\section{B. Research Method}

The research method used in this study is qualitative by using a phenomenological research approach. Phenomenology is a study that describes the everyday social context of the symptoms of human life where the symptoms are formed from the views of those who experience them or rely on the views of the perpetrators and try to understand what is observed from a subjective point of view. In this study, the researcher used the nature of the data needed, namely qualitative, by describing and analyzing the phenomenon of Muhammadiyah's da'wah in Lampung Province.

An important reason why this research uses qualitative research. First, this research is intended to understand the implementation of Muhammadiyah's da'wah in the Lampung region. Second, the effort to see firsthand the reality in the field about Muhammadiyah's da'wah through local cultural wisdom. Third, the problems studied are very dynamic, phenomenal, even comprehensive or universal, not only in urban communities but also in rural communities, maybe even not only in Lampung but maybe also in other areas. Therefore, qualitative research is more effective and makes it easier to collect data. Data and analyze it. 
The source of data in this study is the source of the data. This study was obtained using observations and interviews, namely reviewing the research location and asking some questions to research related to the problem. The source of data is called informants, namely, people who answer or respond to questions, namely Regional Leaders through the Chair of the Tablighi Majlis and their members submitted by researchers, "whether written or oral questions."8 Other data sources are generally used in research or writing scientific papers, books, scientific journals, research reports, bulletins, and magazines. Sources of data in this study will be obtained through primary data and secondary data, which will be explained below:

Primary data is data obtained directly from the field where the research is conducted through predetermined research information, namely those in the research area, have time, and are willing to answer questions, provide information clearly, and understand issues related to the research out. For this reason, in collecting data, researchers carried out directly from the data source, which would be the primary data.

As stated by Sugiyono in the book "Quantitative Research Methods," that respondents should have the following criteria:

a. Those who master or fulfill something through the process enculturation, so that they know and also live;

b. They are classified as still involved or involved in activities being researched;

c. Those who have sufficient time to be asked information.

d. Those who are not inclined to convey result information the packaging itself.

e. They initially felt entirely foreign to the researcher, $s$ exciting to be a teacher or resource person. ${ }^{9}$

Research informants are essential subjects because they will provide information about phenomena that occur in social situations in the field or people who are used to provide information about the situation and condition of the

${ }^{8}$ Suharsimi Arikunto, Manajemen Penelitian, Rineka Cipta, Jakarta, 2010, p. 172.

${ }^{9}$ Sugiyono, Metode Penelitian Kuantitatif, Kualitatif R \& D, Alfabeta, Bandung, 2011, p.221 
object of research. ${ }^{10}$ Given the large population of the study, it is necessary to determine the sample. The selection for this research sample uses a purposive sampling technique; namely, the technique used by the researcher has fulfilled specific considerations or criteria in determining the sample. ${ }^{11}$ of course, the selected informants can provide much information related to research problems in order to simplify and expedite the process of data collection, namely data obtained directly from the research subjects, namely Regional Leaders or Muhammadiyah Branches through the Chair of the Braja Selebah Tabligh Majlis, East Lampung, Chair of the Sendang Agung Lampung Tabligh Majlis Central, Chairman of the Regional Tablighi Council and Head of the Candipuro Branch of South Lampung. The latter is specifically in charge of Muhammadiyah da'wah.

\section{Implementation of Muhammadiyah Da'wah}

Muhammadiyah da'wah in implementing its movement is structured, starting from the central level, regional level, regional level, branch level, and branch level, this is to facilitate the Muhammadiyah da'wah movement in achieving its da'wah goals, at the beginning of the journey of Muhammadiyah da'wah so fast, along with the challenges faced in the past. The time. However, at this time, the movement of Muhammadiyah's da'wah is like flowing water, sometimes enthusiastic, sometimes slow, slow, some active, and some inactive. Members who follow the Muhammadiyah manhaj, members in the middle (moderate), and members who hide their Muhammadiyah.

Its da'wah activities, implementing the Muhammadiyah manhaj, are guided by the qoidah majlis tabligh that Muhammadiyah is an Islamic movement, a da'wah movement, and a tajdid movement, so that all organizational administrators and business charity managers carry out da'wah, both in the fields of tarjih, education, health, social, economic, arts and culture. The existence of a revitalization movement in congregational da'wah, because it becomes the spirit of Muhammadiyah, for Muhammadiyah people must be able to place themselves in

\footnotetext{
${ }^{10}$ Iskandar, Metodologi Penelitian Pendidikan dan Sosial (Kuantitatif dan Kualitatif), Gaung Persada Press, Jakarta, 2008, p. 213.

${ }^{11}$ Suharsimi Arikunto, Op. Cit., p. 90.
} 
society and not touch the problem of the caliphate in the approach of the da'wah movement.

\section{Policies in the Implementation of Muhammadiyah's Da'wah}

Muhammadiyah, in implementing the da'wah movement, is always guided by the articles of association and bylaws of Muhammadiyah, Muhammadiyah ideology, the personality of Muhammadiyah, and guidelines for the Islamic life of Muhammadiyah members. To carry out these da'wah activities, all majlis and sections are part of the da'wah movement, especially the tabligh majlis, which is devoted to managing da'wah activities. It shows that the professionalism of the Muhammadiyah da'wah movement. Structurally, regional leaders, regional leaders, branch leaders, and branch leaders, including Muhammadiyah organizations and charities, start from the central leadership.

Muhammadiyah membership is generally equally divided into three groups; members who follow the Muhammadiyah manhaj, members who are in the moderate, and members who hide their Muhammadiyah. His da'wah activities carried out the Muhammadiyah manhaj, which was flexible, flexible as long as it did not conflict with Islamic teachings. Muhammadiyah held a congregational da'wah movement because it became the spirit of being Muhammadiyah, for Muhammadiyah people to have several abilities (dawah competence, broad religious knowledge, then what is put forward means to be prominent, including fairly well-established material), able to place themselves in society comprehensive in the social life of the community, especially religious life, especially those related to the community's economy and its applicative form is felt directly by the community. It does not touch the problem of the caliphate in the approach of the da'wah movement.

\section{E. The Activeness of Muhammadiyah Members in Da'wah}

The duties of members of Persyarikatan Muhammadiyah must remain active in carrying out the mandate in the Muhammadiyah manhaj, be active and straight following the tarjih. This remains a guideline for members of the 
Muhammadiyah association in their activities. His da'wah activities carry out Muhammadiyah manhaj, which must be able to color all aspects of life, including actively participating in every general local tradition activity, such as Yasinan, Marhabanan, Rajaban, Nuzul Qur'an, Syawwalan, Aqiqohan, Sunnatan, Walimahan. Muhammadiyah provides an opportunity as a tribute to ustadz outside Muhammadiyah to participate in da'wah activities at certain recitation events organized by Muhammadiyah. This builds friendships and attracts sympathizers always to live side by side peacefully, showing that Muhammadiyah is a building organization. Progress in Islam, for example, in the committee for the construction of a mosque.

\section{F. Muhammadiyah Da'wah Guidelines}

Muhammadiyah, in carrying out its da'wah movement, is guided by the AlQur'an and Al-Hadith, which is maqbullah. On the other hand, it uses the Burhani approach, the bayani approach, and the irfani approach. His da'wah activities carried out the Muhammadiyah manhaj. Also, in the da'wah movement, it remains on its manhaj, starting from the life of the family, neighbors, then society in general, so that the da'wah of the congregation is formed. His da'wah activities, Yasinan, are filled with studies or explanations of the interpretation of Surah Yasin or other letters in the Qur'an, and some of them blend in with local traditions.

The existence of a recitation movement for mothers in the congregational da'wah, which was initially the Yasinan congregation, and is now being shifted to a regular study of the Qur'an, until now it is still running twice a month. This shows that da'wah activities start from the family environment, spread to neighbors, and continue to the community, so congregational da'wah is formed. These activities are filled with systematic studies, such as reading the Qur'an, wirid, and dhikr.

\section{G. Muhammadiyah Da'wah Movement to Society}

Muhammadiyah's da'wah continues to move even though some are active at the branch level and inactive. The active ones will color community activities 
such as commemorating Islamic holidays and integrating with society in general. Its da'wah activities, having its center for da'wah activities, and the surrounding community will be integrated with the activities carried out by Muhammadiyah. The congregational da'wah movement, because it is the spirit of Muhammadiyah, is clarified by the Muhammadiyah logo, which is not installed in the mosque.

\section{H. Analysis of Muhammadiyah Da'wah Through Local Cultural Wisdom}

\section{Actively Participate in Community Activities}

First: Muhammadiyah's da'wah goes according to its manhaj, and promotes enlightenment through its cults. Although some are active, and some are inactive. Second; Its da'wah activities, having its center for da'wah activities, and the surrounding community will be integrated with the activities carried out by Muhammadiyah. Third, Muhammadiyah's way of da'wah, for Muhammadiyah people, must be flexible, see, read situations and conditions, such as cult opportunities or lectures and be able to place themselves in a pluralistic society. As said by Kuntowijayo, that "the idea of education pioneered by Kyai Dahlan is a renewal because it can integrate aspects namely "faith" and "progress," so that it can produce a generation of educated Muslims who can live in the modern era without splitting their personalities. "Modern" Islamic educational institutions became the main characteristic of the birth and development of Muhammadiyah, which distinguished it from Islamic boarding schools at that time. "Modern" Islamic education was later adopted and became an educational institution for Muslims in general. The word modernist is an Indonesian word that is always used by the word modern, modernization and modernism are found, for example, in "modern schools in Islam" and "Islam and modernization." This step in the past was a successful reform movement, which gave birth to a generation of educated Muslims, which, if measured by the success of Muslims today, will be different because the context is different. 


\section{Following the Routine Studies conducted by the community}

Muhammadiyah preaching must be at the forefront, a role model for the community with a flexible approach or following the rhythm of the community. Second, His da'wah activities merge with other Islamic communities, and some follow general local traditions, such as Yasinan, Marhabanan, Rajaban, Nuzul Qur'an, Syawwalan, Aqiqohan, Sunnatan, Walimahan, it is okay, the important thing is not to violate the Shari'ah. Islam. Third; Efforts to change from tradition to become more advanced by utilizing the potential of the existing community with the color of Muhammadiyah's da'wah towards progressive Islam, and Muhammadiyah people are required to be able to place themselves in society.

\section{Menjadi Mubaligh atau Penceramah 3. Become a preacher or preacher}

First, Muhammadiyah missionaries must be at the forefront, role models for the community with a flexible approach or follow the rhythm of the community. Second; Da'wah activities, coloring every da'wah activity by providing enlightenment through Muhammadiyah manhaj and although some follow general local traditions, such as Marhabanan, Rajaban, Nuzul Qur'an, Syawwalan, Aqiqohan, Sunnatan, Walimahan, Third; Movement in congregational da'wah, for Muhammadiyah people must be able to place themselves in society as a figure or color and not touch the problem of the caliphate in the approach of the da'wah movement. Seeing this, Muhammadiyah is positioned at the forefront, being uswatun hasanah, driving force, active, creative, and innovative in social life. To carry out the missionary movement of Muhammadiyah, it is necessary to thoroughly look at the potential and condition of the community so that the da'wah movement can achieve the target. 


\section{Muhammadiyah Da'wah and Local Cultural Wisdoms}

Muhammadiyah, in its da'wah movement, continues to run on its manhaj, and this has become its commitment at the level of Muhammadiyah leadership. Second, the da'wah activities carry out Muhammadiyah manhaj and some through local traditional approaches that are general, which do not deviate from Islamic traditions such as Yasinan, Marhabanan, Rajaban, Nuzul Qur'an, Syawwalan, Aqiqohan, Sunnatan, Walimahan. Third; The existence of a coloring movement in the congregational da'wah, because this will be the path of Muhammadiyah's da'wah, for Muhammadiyah people must be able to place themselves in society, even Muhammadiyah's da'wah becomes a part of enlightenment for people's lives.

\section{Muhammadiyah's View on Local Cultural Wisdom}

Muhammadiyah, at the beginning of its development, has been declared an Islamic organization characterized as an Islamic movement, a da'wah movement amar ma'ruf nahi munkar, and a tajdid movement. At first, it was unthinkable that there would be differences of opinion or the emergence of disputes in the affairs of ikhtilafi. As an Islamic organization that dares to declare a modern Islamic organization, of course, many things will happen, starting from contact with traditions, culture, customs, and even disputes in the affairs of the caliphate of Islamic teachings. However, all of that does not stop the Muhammadiyah movement. The Muhammadiyah movement is getting more enthusiastic in its da'wah with the method that has been guided in the holy book AlQur'an Surah An Nahl verse: $125^{12}$ This means: "Ajalah to the way of your Lord with wisdom and good lessons and good discussions too." verse.

\footnotetext{
12Departemen Agama RI Departemen Agama RI, Al-Qur'an dan Terjemahnya (Jakarta, 2010).
} 
This is the guideline for the Muhammadiyah organization in the implementation of Islamic da'wah.

By applying this da'wah method, Muhammadiyah places its position as a flexible da'wah movement full of wisdom, even though it is also not soluble in tradition, customs that shackle society and even gives it a leading color in all things. For example, the new model yasinan activity ala Pak AR". How about we now have a new yasinan model, so that you can gain broader knowledge and gain other experiences? agree?" asked Mr. AR. "Agreed," they answered in unison. "Let us read Surah Yasin." Then read the first verse and continue with the next verse, then one of them was asked to interpret. If not, Mr. AR can help. After being interpreted, then Pak AR explained the contents of the Yasin Letter. He explained at length, accompanied by new examples, filled with a genuine sense of family. Even though that night only read two or three verses, the audience was quite satisfied. Some even asked that it be continued in the next Yasinan. "If I, as a young person, I am up to the audience, but most importantly, it depends on Al Mukarom Angk Ula, our parents in attendance," unexpectedly, the cleric agreed.

Thus, Mr. AR did not immediately ask to fill in every Friday night, so that they alternated. Friday night, an odd night for the old model yasinan who led Angku Ulama. On Friday night, the new model of yasinan filled in Pak AR. After some time, the Angku Ulama handed over the leadership of the yasinan to Mr. $\mathrm{AR}$, and the yasinan became a routine activity of reading Yasin's letter, followed by his interpretation. So, it seems that in the past, Pak AR has also carried out cultural da'wah. Da'wah without disturbing customs and the spirit of the community in glorifying the holy verses of the Koran that have been imprinted for a long time. He is aware and understands that the event has social wisdom, for example, as a place for the unity of the Muslim Ummah, an arena for strengthening friendship, community service, and a moment to improve the quality of Islam, so that it becomes a culture, not as a goal, but only as a means to love Islam, then as a means to get correct information about being Muslim. In 
the end, you will get a complete Islamic life". This is the limit of wisdom to implement Muhammadiyah's da'wah path in its cultural da'wah.

At first, Muhammadiyah in the da'wah movement was oriented to modern thinking. On the other hand, it turned out to be different from what was expected. As expressed by a Muhammadiyah figure known as Pak AR, in full Mr. Kiai Haji Abdur Rozaq Fachruddin, he revealed that the teachings could be carried out under situations and conditions faced by a person or group of people so that it does not complicate but also does not make it easier. Islam is joyful teaching." Furthermore, said by Kuntowijoyo; explaining about Muhammadiyah's da'wah dealing with the context of dual, syncretic, and traditional religious life, on the one hand, it faces a syncretic Islam represented by Javanese court culture and priyai groups as its supporters, on the other hand facing Islam which is still traditional and spread in rural areas with kyai and its Islamic boarding schools. ${ }^{13}$

Kuntowijoyo explained another negative impact if Muhammadiyah is a "cultural movement without culture," the culture developed by Muhammadiyah is very elitist, so it cannot reach the lower layers of Muslims. This happened because Muhammadiyah did not try to change traditions from within but instead formed a new movement based on urban communities. For a long time did not accommodate people in rural areas who still held traditions. Kuntowijoyo analyzes the dryness of the cultural mission within Muhammadiyah on the structure behind the early supporters of Muhammadiyah, namely the urban-village community, and his attention is focused on meeting the materialistic demands of modernization. Muhammadiyah tends to be pragmatic. It fulfills the needs of modern society and has not yet had time to explore the nature of humanity, so that life can only be handled by formal and organizational technical means. ${ }^{14}$

Looking at the study of Kuntowijoyo and Munir Mulkan's understanding of Muhammadiyah's da'wah movement in implementing it, it turns out that each

\footnotetext{
${ }^{13}$ wijiyo, Dinamika Sejarah Umat Islam Indonesia, p. 256.

${ }^{14}$ Kuntowijoyo, Op Cit, p. 268-269
} 
has its peculiarities, especially when dealing with local community culture. This will expand Muhammadiyah's thinking in developing Islamic society's thinking, which affects the change of people's thinking. At first, people who are still thick with local culture, then touched by modern thoughts, more or less there will be changes in behavior in people's lives. At first, those who lived mediocrely, but after there was an increase in welfare, in the end, their lifestyle changed, which was previously uneducated, after getting to know the world of education, there was a change in mindset which resulted in changes in the thinking of the structure of society, people's behavior, culture also shifted to the realm of progress.

This is as stated by Fauzi Nurdin in his book "Islam and Social Change." Understanding the meaning and symbols of religion by its adherents is closely related to values, norms, culture, and social structures in society. That understanding can be studied through a sociological approach. According to Auguste Comte, even if religion can survive, it is only a religion of humanity based on science. Religious principles have been given other meanings according to the situation and conditions in which humans live. ${ }^{15}$

The concept of empowerment of da'i (preacher) in society refers to theories related to social change that are focused on community development by combining evolutionary theory, cycle theory, functional theory, and conflict in Koentjaraningrat. The theory of evolution holds that social change has a fixed direction through which all societies pass through the same sequence of stages. Starting from the initial stages of development to the ideal final development, while the cycle theory explains the existence of many stages (growth, childhood, adolescence, adulthood, and extinction) that must be passed by society when it has reached the final stage, then it rotates back to the initial stage. for the next transition.

The functional theory explains that functionally valuable changes are accepted, and other changes that prove useless (dysfunctional) are rejected. The

15 Fauzi Nurdin, Islam dan perubahan Sosial, Penerbit ; Reality Press, 2012, p. 39-41. 
conflict theory considers that what is constant is social conflict, not change. Changes occur due to the conflict, and if the conflict continues, the change will continue as well. Understanding the experience of religion or religious practice in people's lives in this study can be explained by functional theory because functional theory can explain the phenomenon of da'i empowerment in local communities, especially in rural areas.

Malinowski emphasized, the function is to fulfill individual needs as citizens of society, and society is analogous to organic life, while RedcliffeBrown's orientation is not individual but a community. According to the functional theory, it is clear that what is seen is a social reality that together forms the social organism as a whole. The social organism consists of units which, in a society, some devices can be unified. In this theoretical study, the functional theory was refined by Talcott Parsons, whose opinion differs from that of the two anthropologists. He builds his theory by referring to the system, where society is seen as a system, namely a unit consisting of sub-systems or units consisting of some units that interact with each other. The relationship between one unit is called a structure. In this process, there is also a mutual need between one unit and another. Each sub-system or unit has a function in a system in the form of donations of specific units in meeting the system's needs. ${ }^{16}$

Change is not a result, but it does occur naturally, even though, in reality, it occurs as a result of a transformation of science, culture, and behavior. This is what happens. The fact states that social change, including culture and behavior, is evidence of thoughts that cause change.

As Muhammadiyah's da'wah movement through local cultural wisdom can influence the community's mindset, both socially, culturally, and even the behavior of people's lives. The research data shows that da'wah, through local cultural wisdom, is considered very important because the da'wah movement does not appear to be a da'wah movement and follows the flow of existing 
community life. Even so, of course, you should not drift in helplessness following the flow of life; you have to be a color, being an example of uswatun hasanah in social life as an example of the following data:

Muhammadiyah, through the practice of its da'wah movement, is getting more mature and very experienced in strategizing the way of da'wah, especially when dealing with traditional communities, Muhammadiyah always puts itself in a comfortable position, makes them smile, feels the pleasure of believing in Islam, feels comfortable living side by side with Muhammadiyah or other people. Muhammadiyah's presence in a traditional society that is thick with culture can certainly provide enlightenment through various fields, both in education, economics, social, politics, culture, and art. ${ }^{17}$ One of the scholars from Muhammadiyah, Abdul Munir Mulkhan, said that there are two consequences of such a cultural direction: First is the nature of elitism that has made Muhammadiyah a privilege for the middle-upper class. The second is the shift from a socio-cultural reform movement to a movement stuck on fiqh issues. This happens because modernists have gone too far by making materialism and rationalism no longer just analytical tools but as ideologies. ${ }^{18}$

Furthermore, Kuntowijoyo explained another negative impact, if Muhammadiyah was a "cultural movement without culture," because the culture developed by Muhammadiyah was elitist, so it could not reach the lower layers of Muslims. This happened because Muhammadiyah did not try to change traditions from within but formed a new movement based on urban communities. Moreover, for a long time did not accommodate people in rural areas who still hold on to traditions. Kuntowijoyo analyzes the dryness of the cultural mission in Muhammadiyah on the structure behind the early supporters of Muhammadiyah, namely the urban-urban community, whose attention is more focused on meeting the demands of materialistic modernization. 19

Muhammadiyah tends to be pragmatic. It fulfills the immediate needs of modern society and has not had time to explore the nature of humanity. It is as

\footnotetext{
${ }^{17}$ Deden Sumpena, "Islam dan Budaya Lokal: Kajian terhadap Interelasi Islam dan Budaya Sunda" 6, no. 19 (2012), p. 103-5.

${ }^{18}$ Abdul Munir Mulkan, Pemikiran KHA. Dahlan dan Muhammadiyah dalam Perspektif Perubahan Sosial, Penerbit Bumi Aksara, Jakarta, 1990, p. 11

${ }^{19}$ PDM Jakarta Timur, “Gerakan Pemikiran Muhammadiyah: Antara Purifikasi dan Modernisasi,” 2012, http://jaktim.muhammadiyah.or.id/berita/print/883/gerakan-pemikiran-muhammadiyahantara-purifikasi-dan-modernisasi.html.
} 
if life can only be managed technically, formally, and organizationally. The minuses are inherent in almost every action and consistently minimize the minuses with a series of reformative activities. The capital already exists. The existence of Muhammadiyah itself is something extraordinary. Of course, this would be different if Muhammadiyah took the form of a political organization; wouldn't Islamic political parties experience ups and downs, rises and falls.

Muhammadiyah was relatively successful in attracting members and sympathizers and became the second-largest religious organization. Indirectly, Muhammadiyah encouraged the birth of various other organizations such as Nahdlatul Ulama (NU) to stimulate modernization in Islam. Furthermore, the color of Islamic renewal is more prominently determined by the dialectical process of Muhammadiyah and NU on the stage of Indonesian history. It is usually accepted that religion is considered the most difficult element and the slowest to change or be affected by other cultures compared to other elements such as social organization systems, knowledge systems, language, arts, ties created by livelihood systems, technology systems, and equipment.

In the long history of the life of the Indonesian nation, it cannot be fully adapted to this assumption. Various religions came and developed in waves to Indonesia, replacing the old religion and instilling new religious teachings one after another, but in reality, the livelihood system and technology and equipment systems, which were said to be the most accessible elements, turned out to be the most difficult has slightly changed from pre-Hinduism to the present. The historical experience shows that religion changes faster. It changes first before others experience changes. History proves that religious thought is very influential for the development of material aspects (life in this world), whether political, economic, social, or cultural, or in other words, there is a very significant relationship between progress in the field of thought (immaterial) and progress in the material field. ${ }^{20}$

20Deni Miharja, Persentuhan Agama Isam Dengan Kebudayaan Asli Indonesia, MIQOT: Jurnal Ilmuilmu Keislaman 38, no. 1 (June 2, 2014): 199, doi:10.30821/miqot.v38i1.97. 
In the case of Islam, religious thought is also constantly undergoing renewal to give meaning to changes and developments in life in the world in each of its manifestations, but Islamic renewal in the modern era has not succeeded optimally and feels less effective; as a consequence in the material field, Muslims are also still lagging behind Western civilization. Indeed, some Islamic countries have been able to follow the development of modern technology. However, because it has not been supported by religious thought to support it, the results are still far from satisfactory.

M. Amin Abdullah assessed that the root of the rejection of the TB tradition was based on classical scholarship, which was heavily influenced by black-and-white Greek logic, so it could not explain the realities of life on the ground. The configuration and the map of the mindset are too schematic, so they cannot consider an overlapping configuration (jumbo position), which involves part of the two sides at once. At the same time, the texts of the Qur'an itself allow for the "middle" category, which needs to be looked at more seriously. ${ }^{21}$

Kuntowijoyo mengkritik TBC masih ditampilkan dalam realitas subyektif, dan belum ditampilkan secara empiris-obyektif, dimana kita berada dalam stuktur sosial yang berbeda. Konsep klasik tentang TBC yang disusun dengan cara pikir deduktif yang menekankan segi rasio perlu dilengkapi dengan cara pikir induktif yang bersifat empiris-historis.

The dominance of textual normative religious understanding tends to ignore historical contextual Islamic studies. This is what makes Muhammadiyah's thoughts feel less actual and irrelevant to the rapid social change. Therefore, people are more familiar with the Muhammadiyah movement as an anti-TBC (Tahayul, Bid'ah dan Churafat) movement and not a socio-cultural reform movement.

21Parluhutan Siregar, Integrasi Ilmu-Ilmu Keislaman Dalam Perspektif M. Amin Abdullah, MIQOT: Jurnal Ilmu-ilmu Keislaman 38, no. 2 (December 9, 2014): 338, doi:10.30821/miqot.v38i2.66. 


\section{CONCLUSION}

The implementation of Muhammadiyah's da'wah has opened the way of da'wah for the advancement of Islam with its characteristics as an Islamic movement, the amar ma'ruf nahi munkar da'wah movement and the tajdid movement, through majlis, both tabligh majlis, tarjih majlis, education, economy, health, politics and socio-cultural, all of which are oriented as a way of da'wah, which aims to uphold and uphold the religion of Islam so that a truly Islamic society can be realized. Muhammadiyah implements the da'wah movement through local cultural wisdom with a model of flexibility and wisdom. However, some of these local cultures are not commonly practiced in Muhammadiyah, such as Yasinan, Rajaban, Nuzul Qur'an, Syawwalan, Aqiqohan, Sunnatan, Walimahan, local culture is used as a medium. Da'wah is a place to provide enlightenment to traditions, customs that shackle society, prioritize the benefit of the people, become uswatun hasanah in family life, society, and nation so that Islam truly becomes a religion is spiritually lil'alamin.

Muhammadiyah's Da'wah in the construction of ummatan wasathon, is a choice of da'wah path that is developed through the spirit of progressive Islam, making itself a middle-class ummah, moderate ummah, superior, creative, innovative and civilized Muslims, dynamic middle-class ummah and possessing superior character. "khaira ummah." It is described explicitly in the Qur'an that "ummatan wasathan" becomes "martyrdom 'ala al-nas" (Surah al-Baqarah: 143), thus giving the greatest and best mandate for himself, his family, society, nation, and humankind as a whole.

\section{REFERENCES}

Ahmad, Nur. Tantangan Dakwah Di Era Teknologi Dan Informasi (2013).

Anggaran Dasar Dan Anggaran Rumah Tangga Muhammadiyah. 5th ed. Yogyakarta: Surya Sarana Grafika, 2010. http://www.suaramuhammadiyah.or.id.

Departemen Agama RI, Departemen Agama RI. Al-Qur'an dan Terjemahnya. Jakarta, 2010. 
Fajrie, Mahfudlah. Metode Dan Strategi Dakwah Muhammadiyah Di Kabupaten Demak, .

Hidayat, Syamsul. Metode Pemahaman Agama Dalam Muhammadiyah Kajian Atas al-Masail al-Khams dan MKCH," n.d.

Jakarta Timur, PDM. Gerakan Pemikiran Muhammadiyah: Antara Purifikasi dan Modernisasi, http://jaktim.muhammadiyah.or.id/berita/print/883/gerakan-pemikiranmuhammadiyah-antara-purifikasi-dan-modernisasi.html.

Jauhari Ritonga, Hasnun. Komunikasi organisasi dalam mengatasi konflik dan pencitraan pada organisasi kemasyarakatan islam di sumatera utara." Disertasi, uin sumatra utara, 2018.

Miharja, Deni. Persentuhan Agama Isam Dengan Kebudayaan Asli Indonesia." MIQOT: Jurnal Ilmu-ilmu Keislaman 38, no. 1 (June 2, 2014). doi:10.30821/miqot.v38i1.97.

Mulia, Muji. Islam Dan Transformasi Sosial Dalam Perspektifmkuntowijoyo, Vol. 3, no. 2 (2018): 14 .

Mulkan, Abdul Munir. Islam Yang Menggembirakan. Yogyakarta: Metro Kotagede, 2010.

Nurdin, A Fauzi. Islam Dan Perubahan Sosial. Jakarta: Reality Press, 2012.

Siregar, Parluhutan. Integrasi ilmu-ilmu keislaman dalam perspektif M. Amin abdullah." MIQOT: Jurnal Ilmu-ilmu Keislaman 38, no. 2 (December 9, 2014). doi:10.30821/miqot.v38i2.66.

Sumpena, Deden. "Islam dan Budaya Lokal: Kajian terhadap Interelasi Islam dan Budaya Sunda" 6, no. 19 (2012): 20.

“Tinjauan Buku: Spirit Gerakan Muhammadiyah terhadap Kebudayaan," 2020. https://pmb.lipi.go.id/tinjauan-buku-spirit-gerakan-muhammadiyahterhadap-kebudayaan/.

Umar, Umar. "Strategi Dakwah Kultural Muhammadiyah pada Ritual Adat Mappogau Hanua Masyarakat Karampuang Sinjai." Afkaruna: Indonesian Interdisciplinary Journal of Islamic Studies 13, no. 2 (2017). doi:10.18196/AIIJIS.2017.0073.204-239.

wijiyo, Kunto. Dinamika Sejarah Umat Islam Indonesia. Jakarta: Shalahudin Press dan Pustaka Jaya, 1985.

Inilah Yasinan Bernilai Tinggi ala Pak AR Fachruddin, 2014. https://sangpencerah.id/2014/11/inilah-yasinan-bernilai-tinggi-ala-pak. 